\title{
Waterpipe smoking in Kuwait
}

H.R. Mohammed, ${ }^{7}$ Y. Zhang, ${ }^{2}$ I.M. Newman ${ }^{3}$ and D.F. Shell ${ }^{4}$

$$
\begin{aligned}
& \text { تدخين الشيشة (النَّْهيلة) في الكويت }
\end{aligned}
$$

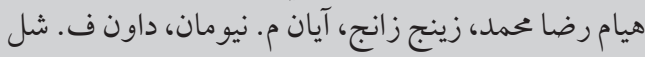

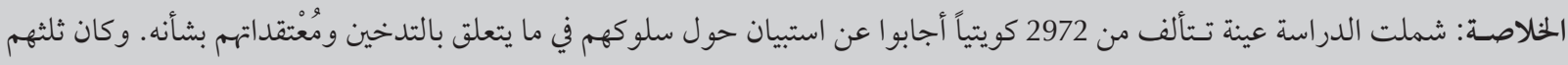

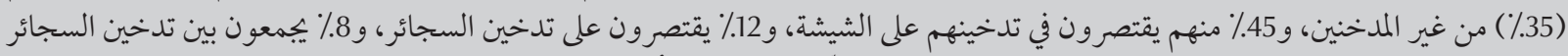

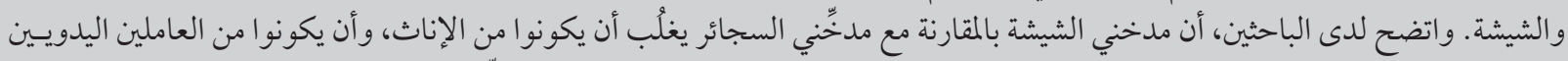

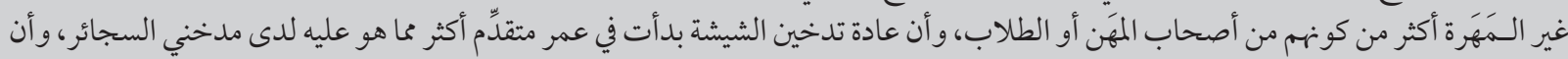

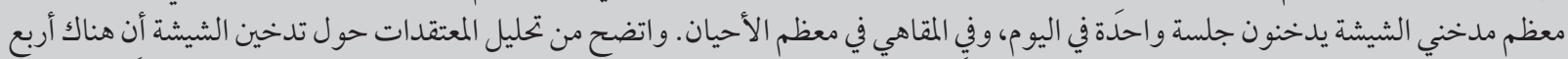

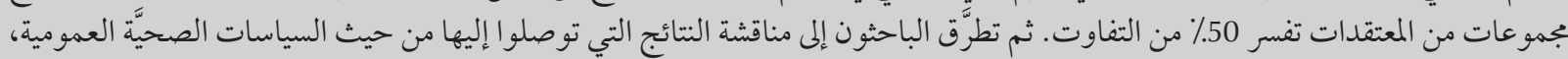$$
\text { ومن حيث استـر اتيجيات تقليص المخاطر. }
$$

ABSTRACT A nonrandom sample of 2972 Kuwaitis answered a questionnaire about smoking behaviour and beliefs. More than one-third (35\%) were nonsmokers, 45\% smoked only the waterpipe, 12\% only cigarettes and $8 \%$ both waterpipe and cigarettes. Compared with cigarette smokers, waterpipe smokers were more likely to be female and to be unskilled manual workers than professionals or students. Waterpipe smokers started the habit at an older age on average than cigarette smokers. Most waterpipe smokers smoked only 1 bowl per day, and smoked mostly at coffee houses. Factor analysis of beliefs about waterpipe smoking resulted in 4 groups of beliefs which explained $50 \%$ of the variance. The results are discussed in terms of public health policy and possible risk reduction strategies.

\section{Usage de la pipe à eau au Koweït}

RÉSUMÉ Un échantillon non aléatoire de 2972 Koweïtiens a répondu à un questionnaire sur le comportement et les croyances liés au tabagisme. Plus d'un tiers (35\%) étaient des non fumeurs, 45 \% fumaient uniquement la pipe à eau, $12 \%$ uniquement la cigarette et $8 \%$ la pipe à eau et la cigarette. Comparés aux fumeurs de cigarettes, les fumeurs de pipe à eau étaient plus souvent des femmes et des travailleurs manuels non qualifiés que des professionnels ou des étudiants. Les fumeurs de pipe à eau avaient commencé en moyenne à un âge plus avancé que les fumeurs de cigarettes. La plupart des fumeurs de pipe à eau fumaient une fois (un foyer) par jour seulement, et principalement dans des cafés. Une analyse des facteurs des croyances sur l'usage de la pipe à eau a permis de définir quatre groupes de croyances qui expliquaient $50 \%$ de la différence. Les résultats sont discutés en termes de politique de santé publique et de stratégies possibles de réduction des risques. 


\section{Introduction}

The waterpipe (also called sheesha, narghile and hubble-bubble) allows smokers to inhale smoke from a special mix of tobacco after it has passed through water. It has a long history and has traditionally been popular in Middle Eastern countries. Waterpipe use now is increasing in popularity in other parts of the world and can be found in places as divergent as Beijing and small towns in the United States of America (USA). As waterpipe use spreads and becomes recognized as an important public health challenge, public health professionals need to observe and record the patterns of use in order to refine public health policies and practices.

It is difficult to estimate the worldwide prevalence of waterpipe use as most surveys have been carried out in Middle East countries. Some studies have suggested that more than 100 million people smoke waterpipes each day [1]. In Kuwait, it is estimated that more than half of both males and females have smoked a waterpipe at least once in their lives, and a considerable proportion began use in their teens [2]. Waterpipe smoking appears to be more acceptable for women than cigarette smoking. Furthermore, because it is a group activity and sometimes a family activity, it is more acceptable for young people to smoke waterpipe than cigarettes.

There is a perception that smoking waterpipe is less harmful than smoking cigarettes, which could account for its popularity [3]. Waterpipe smokers believe that the nicotine content in the tobacco used in waterpipe is lower than in cigarettes and that the harmful products in the smoke are filtered as it passes through the water. Because of the humidity, the smoke is thought to be more soothing and less harmful to the throat and respiratory system than cigarette smoking. Waterpipe smokers believe fewer carcinogens are inhaled because the tobacco in waterpipes is heated and not burned. The fruits and honey added to the tobacco are thought by many people to make smoking healthy [4].

Contrasting these beliefs are studies that suggest no reduced health risks and possibly additional risks because the tobacco mix and the products used for combustion are unregulated. Compared with smoking a cigarette, $45 \mathrm{~min}$ utes of waterpipe smoking is equivalent to double the carbon monoxide (CO) exposure and triple the nicotine exposure [5]. Long-term use of waterpipes has been associated with lung cancer $[6,7]$, gastrointestinal cancer $[8]$ and decreased lung function [9-11]. Studies in Saudi Arabia found that waterpipe smokers had significantly higher levels of carboxyhaemoglobin compared with cigarette smokers $[12,13]$, an indication of greater carbon monoxide exposure. The manner in which the waterpipe is smoked may compound its risks. Waterpipe smokers often spend long periods of time inhaling smoke and, because the smoke is humid and cool, may inhale it more deeply than cigarette smoke. However, the common practice of smoking only 1 bowl of tobacco a day and not necessarily smoking every day may lessen the risks.

In our earlier paper [14], we described the waterpipe habits of students in the Public Authority for Applied Education and Training in Kuwait city. The current study describes the differences between waterpipe smokers, cigarette smokers and nonsmokers in selected groups of Kuwaiti people.

\section{Methods}

\section{Sample}

This sample of 2972 Kuwaitis included 345 (11.6\%) first-year students from Kuwait University, 513 (17.3\%) students from the Kuwait interior police academy, 1581 (53.2\%) unskilled manual workers at universities, schools, restaurants and coffee shops in Kuwait city and 533 (17.9\%) professional workers, including teachers, physicians and postgraduate researchers. The sample was not random. Rather it consisted of selected groups thought to be important and representative of different sectors of Kuwaiti society. The data were gathered by trained data collectors in a variety of settings, such as organized meetings or in classes where permission to carry out the survey was granted. Of those asked to participate, 2972 (82\%) returned usable questionnaires.

\section{Questionnaire}

The questionnaire was a modified version of a questionnaire developed for a study of waterpipe smoking among teachers in training in Kuwait city [15]. Questions were derived from the published literature on waterpipe use and discussions with waterpipe users. The questionnaire was pilot tested, revised and retested to achieve acceptable reliability [15]. The questionnaire logic was based on the behavioural assessment phase of Green and Kreuter's PrecedeProceed Model, which identified variables that predispose a person to smoke waterpipe, facilitate waterpipe smoking and reinforce waterpipe use [16].

The 33-item questionnaire asked 4 demographic questions, 9 questions about smoking behaviour and 20 questions about beliefs about waterpipe smoking. The belief questions were answered on 5-point Likert scales with scores ranging from $1=$ strongly disagree to $5=$ strongly agree. We used an exploratory factor analysis with varimax rotation to statistically group beliefs that were related.

Waterpipe smokers were those who had been smoking waterpipes for at least 1 month and were smokers at the time of the survey. Cigarette smokers were defined the same way: having smoked cigarettes for at least 1 month and were smokers at the time of the survey.

\section{Statistical analysis}

Questionnaire response variables were entered into a database for analysis. SPSS, version 12 was used to analyse 
the descriptive data and to conduct the factor analysis.

\section{Results}

\section{Background characteristics}

Table 1 shows the demographic characteristics of the sample. Professionals (75.6\%) and university students (73.6\%) were more likely to be male than female. Police academy students were almost exclusively male (99.6\%). Unskilled manual workers were most likely female (74.4\%). Professionals included the largest proportion aged $\geq$ 25 years $(88.2 \%)$; university students and police academy students included the largest proportion aged $<25$ years ( $94.8 \%$ and $90.4 \%$ respectively).

Table 2 shows that at the time of the survey, 1035 (35.0\%) of the sample identified themselves as nonsmokers, 1321 (44.6\%) smoked only waterpipe, 368 (12.4\%) smoked only cigarettes, and 235 (8.0\%) smoked both waterpipe and cigarettes. Type of smoking significantly differed by age (Table 2). People who smoked waterpipe only and who smoked both waterepipe and cigarettes were more likely to be aged $<25$ years, and nonsmokers were more likely to be $\geq 25$ years. Type of smoking significantly differed by sex (Table 2). Women were more likely to smoke waterpipe only, whereas males were more likely to be nonsmokers, smoke cigarettes only or smoke both waterpipe and cigarettes. Type of smoking significantly differed by occupation (Table 2). Professionals were more likely to be nonsmokers, manual workers were more likely to smoke waterpipe only and police academy students were more likely to smoke cigarettes only or smoke both waterpipe and cigarettes.

\section{Quantity of waterpipe smoking}

Among waterpipe only smokers $47.9 \%$ smoked 1 bowl a day, $21.4 \%$ more than 1 bowl a day and $12.9 \% 1$ bowl a week. Of those who smoked both waterpipe and cigarettes $41.9 \%$ smoked 1 bowl a day, $23.9 \%$ more than 1 bowl a day and $16.7 \% 1$ bowl a week. The remaining $17 \%$ of both groups smoked less than 1 bowl a week.

Most waterpipe smoking was done in coffee shops (39.7\% of waterpipe only smokers and $50.6 \%$ of those who smoked both waterpipe and cigarettes). Home was the choice of $14.9 \%$ of waterpipe only smokers and $12.3 \%$ of those who smoked both waterpipe and cigarettes. The remainder smoked in many places: at home, in coffee shops and many other social settings.

\section{Age of first use of waterpipe}

Regular waterpipe smoking started later in life than regular cigarette smoking. Most waterpipe only smokers (63.5\%) became regular waterpipe smokers after age 17 years compared with $49.0 \%$ of cigarette only smokers. For the people who smoked both waterpipe and cigarettes $46.1 \%$ began smoking cigarettes after age 17 years and $46.6 \%$ began smoking waterpipe after this age.

\section{Friends' use and peer pressure to smoke waterpipe}

Half (50.6\%) of the waterpipe only smokers reported that all or most of their friends smoked waterpipes compared with $42.2 \%$ of the cigarette only smokers and $65.7 \%$ of those who smoked both waterpipe and cigarettes.

Almost half (47.5\%) of the waterpipe smokers said it was friends who first encouraged them to try the waterpipe. Among the non-waterpipe smokers (people who had smoked waterpipe some time in their life, but not in the 30 days before the survey), $53.7 \%$ of cigarette smokers said it was their friends who had encouraged them to try waterpipe compared to $42.3 \%$ of nonsmokers (people who smoked for less than 1 month in their life and were not smoking at the time of the survey).

\section{Quitting waterpipe use}

More than half (57.7\%) of the waterpipe smokers and $52.6 \%$ of those who smoked both waterpipe and cigarettes had tried to quit smoking waterpipes some time in the past. However, the study did not explore the reasons for quitting or the reasons attempts to quit were not successful.

\section{Beliefs about waterpipe use}

Factor analysis of beliefs about waterpipe smoking resulted in 4 groups of beliefs which explained $50 \%$ of the variance. Table 3 lists the waterpipe-

\begin{tabular}{|c|c|c|c|c|c|c|c|c|c|c|}
\hline \multirow[t]{2}{*}{ Variable } & \multicolumn{2}{|c|}{$\begin{array}{l}\text { Professional } \\
\quad(n=533)\end{array}$} & \multicolumn{2}{|c|}{$\begin{array}{l}\text { Unskilled manual } \\
\qquad(n=1581)\end{array}$} & \multicolumn{2}{|c|}{$\begin{array}{l}\text { University student } \\
\qquad(n=345)\end{array}$} & \multicolumn{2}{|c|}{$\begin{array}{l}\text { Police academy student } \\
\qquad(n=513)\end{array}$} & \multicolumn{2}{|c|}{$\begin{array}{c}\text { Total } \\
(n=2972)\end{array}$} \\
\hline & No. & $\%$ & No. & $\%$ & No. & $\%$ & No. & $\%$ & No. & $\%$ \\
\hline \multicolumn{11}{|l|}{ Sex } \\
\hline Male & 403 & 75.6 & 405 & 25.6 & 254 & 73.6 & 511 & 99.6 & 1573 & 52.9 \\
\hline Female & 130 & 24.4 & 1176 & 74.4 & 91 & 26.4 & 2 & 0.4 & 1399 & 47.1 \\
\hline \multicolumn{11}{|c|}{ Age (years) } \\
\hline$<25$ & 63 & 11.8 & 836 & 52.9 & 327 & 94.8 & 464 & 90.4 & 1690 & 56.9 \\
\hline$\geq 25$ & 470 & 88.2 & 743 & 47.1 & 18 & 5.2 & 49 & 9.6 & 1280 & 43.1 \\
\hline
\end{tabular}




\begin{tabular}{|c|c|c|c|c|c|c|c|c|c|c|}
\hline \multirow[t]{2}{*}{ Variable } & \multicolumn{2}{|c|}{$\begin{array}{l}\text { Nonsmokers } \\
(n=1035)\end{array}$} & \multicolumn{2}{|c|}{$\begin{array}{c}\text { Waterpipe only } \\
\text { smokers } \\
(n=1321)\end{array}$} & \multicolumn{2}{|c|}{$\begin{array}{l}\text { Cigarette only } \\
\text { smokers } \\
(n=368)\end{array}$} & \multicolumn{2}{|c|}{$\begin{array}{l}\text { Both waterpipe } \\
\text { and cigarette } \\
\text { smokers } \\
(n=235)\end{array}$} & \multicolumn{2}{|c|}{ Statistics } \\
\hline & No. & $\%$ & No. & $\%$ & No. & $\%$ & No. & $\%$ & & \\
\hline \multicolumn{11}{|l|}{ Age (years) } \\
\hline$<25$ & 475 & 45.9 & 852 & 64.5 & 194 & 52.7 & 167 & 71.1 & \multirow{2}{*}{$\chi_{3}^{2}=104.04$} & \multirow{2}{*}{$P<0.001$} \\
\hline$\geq 25$ & 559 & 54.1 & 468 & 35.5 & 174 & 47.3 & 68 & 28.9 & & \\
\hline \multicolumn{11}{|l|}{ Sex } \\
\hline Male & 749 & 72.4 & 265 & 20.1 & 336 & 91.3 & 213 & 90.6 & \multirow{2}{*}{$\chi_{3}^{2}=1081.15$} & \multirow{2}{*}{$P<0.001$} \\
\hline Female & 286 & 27.6 & 1056 & 79.9 & 32 & 8.7 & 22 & 9.4 & & \\
\hline \multicolumn{11}{|l|}{ Occupation } \\
\hline Professional & 367 & 35.5 & 39 & 3.0 & 93 & 25.3 & 26 & 11.1 & \multirow{4}{*}{$\chi_{9}^{2}=1383.67$} & \multirow{4}{*}{$P<0.001$} \\
\hline Unskilled manual & 253 & 24.4 & 1178 & 89.2 & 102 & 27.7 & 44 & 18.7 & & \\
\hline $\begin{array}{l}\text { University } \\
\text { student }\end{array}$ & 191 & 18.5 & 33 & 2.5 & 58 & 15.8 & 63 & 26.8 & & \\
\hline $\begin{array}{l}\text { Police academy } \\
\text { student }\end{array}$ & 224 & 21.6 & 71 & 5.4 & 115 & 31.3 & 102 & 43.4 & & \\
\hline
\end{tabular}

13 questionnaires had missing data.

related belief factors and their statistical weights; 8 questions loaded on the 1st factor that represented beliefs about the negative health effects of smoking waterpipes; 4 items loaded on the 2nd factor that described beliefs about the positive personal benefits of smoking waterpipes; 4 items loaded on the $3 \mathrm{rd}$ factor that described beliefs about the social reasons for smoking waterpipes; 3 items loaded on the 4th factor that described beliefs about the negative personal effects of smoking waterpipes; and 1 item was deleted because of poor loadings on all factors.

Table 4 summarizes the belief factor scores for the 4 smoking types. An analysis of variance test of the factor scores indicated a significant difference in all the 4 factor scores between the 4 smoking types: $F(3,2955)=21.38, P<$ 0.001 for factor $1 ; F(3,2955)=19.39, P$ $<0.001$ for factor $2 ; F(3,2955)=17.96$, $P<0.001$ for factor 3 ; and $F(3,2955)=$ $10.49, P<0.001$ for factor 4 . Further post hoc analysis explored the differences.

Nonsmokers held significantly strongerbeliefs about thenegativehealth effects of waterpipe than did smokers. Smokers (waterpipe or cigarettes or both) did not differ in their beliefs about the negative health effects.

Those who smoked both waterpipe and cigarettes held the strongest beliefs about the positive personal benefits of smoking. Waterpipe only smokers had significantly stronger beliefs about the positive personal benefits of waterpipe than nonsmokers. Cigarette only smokers did not significantly differ from nonsmokers in their beliefs about the positive personal benefits of smoking waterpipe.

Nonsmokers and cigarette only smokers more strongly believed in the social reasons for smoking waterpipe than waterpipe only smokers and people who smoked both waterpipe and cigarettes. In other words, the nonsmokers and cigarette smokers believed it was social pressures that encouraged people to smoke waterpipes, whereas the waterpipe only smokers and those who smoked both waterpipes and cigarettes did not believe social pressures were a cause of waterpipe use.

For the last factor, people who smoked both waterpipe and cigarettes were the least likely to believe in the negative personal effects of waterpipe. The waterpipe only smokers were also less likely than nonsmokers to believe in the negative personal effects of waterpipe. The differences in the strength of beliefs between waterpipe only smokers and cigarette only smokers, and between cigarette only smokers and nonsmokers were not significant.

\section{Discussion}

Our results show that, unlike cigarette only smoking, waterpipe only smoking was more common among females (79.9\%) than males (20.1\%). Research in the Syrian Arab Republicsuggests that women perceived waterpipe smoking more positively than cigarette smoking because of its traditional characteristics and the fact that it was often smoked in social setting with friends [17]. Clearly there is a need to learn more about the psychosocial aspects of waterpipe use and why it is so popular among woman.

Smoking started at a later age for people who smoked only waterpipes compared with people who smoked only cigarettes. This means there are more opportunities for prevention of 


\begin{tabular}{|c|c|c|c|c|}
\hline \multirow[t]{2}{*}{ Item } & \multicolumn{4}{|c|}{ Component } \\
\hline & 1 & 2 & 3 & 4 \\
\hline $\begin{array}{l}\text { Smoking waterpipes is associated with diseases such as heart disease and high blood } \\
\text { pressure }\end{array}$ & 0.787 & - & - & - \\
\hline Smoking waterpipes is associated with lung cancer & 0.747 & - & - & - \\
\hline Sharing a waterpipe mouthpiece can lead to transmission of infectious diseases & 0.710 & - & - & - \\
\hline Inhaling smoke from parents' waterpipes harms the health of babies and children & 0.682 & - & - & - \\
\hline Waterpipe smoking is associated with decreased oxygen in the blood & 0.659 & - & - & - \\
\hline Smoking waterpipes daily for a period of time might cause mouth ulcers & 0.506 & - & - & - \\
\hline Waterpipes have more carbon monoxide than cigarettes & 0.447 & - & - & - \\
\hline The water in waterpipes helps filter cancer-causing chemicals & 0.313 & - & - & - \\
\hline I feel or felt comfortable and relaxed when I smoke waterpipes & - & 0.827 & - & - \\
\hline I look or looked cool when I smoke waterpipes & - & 0.796 & - & - \\
\hline I enjoy or enjoyed smoking waterpipes & - & 0.730 & - & - \\
\hline I like or liked the different flavours of ma'asel (waterpipe tobacco) & - & 0.717 & - & - \\
\hline I started smoking waterpipes when I felt pressure from my friends & - & - & 0.754 & - \\
\hline I started smoking waterpipes in a social setting & - & - & 0.736 & - \\
\hline $\begin{array}{l}\text { Watching TV, video/DVD or going to the movies and seeing actors smoking } \\
\text { waterpipes encouraged me to start smoking waterpipe }\end{array}$ & - & - & 0.550 & - \\
\hline I lose my friends if I don't smoke waterpipes with them & - & - & 0.493 & - \\
\hline I smell or smelled bad after smoking waterpipes & - & - & - & 0.738 \\
\hline I waste or wasted a lot of time smoking waterpipes & - & - & - & 0.664 \\
\hline I feel or felt tense after smoking waterpipes & - & - & - & 0.629 \\
\hline
\end{tabular}

initiation of waterpipe smoking. People who smoked both waterpipe and cigarettes had a starting age similar to cigarette smokers. This means that prevention programmes aimed at reducing cigarette smoking should also address waterpipes.

In our survey, waterpipe smokers were most likely to be unskilled manual workers. The workplace can be an importantsite for cessation and prevention programmes. Work site programmes can be tailored to the needs of specific groups of workers and this would potentially improve their effectiveness.

Peer influence has been identified as an important factor in a wide range of behaviours $[18,19]$. Nevertheless $42.3 \%$ of nonsmokers said they were encouraged to smoke the waterpipe by their friends but somehow they resisted this pressure. Research attention needs to be directed at understanding those who do not smoke waterpipe or cigarettes to better understand the reasons they never adopted these unhealthy behaviours.
Waterpipe smokers had more positive beliefs about waterpipe smoking than nonsmokers and these responses suggest that they were less knowledgeable about the health effects of waterpipe smoking. Beliefs serve as mediators for smoking behaviour, so correcting inaccurate beliefs and reinforcing correct beliefs should be an important part of any educational programme to reduce waterpipe smoking.

Approximately half the waterpipe smokers in this sample had tried at least

\begin{tabular}{lcccc}
\hline Table 4 Factor scores of the 4 types of smokers & Nonsmokers & $\begin{array}{c}\text { Waterpipe only } \\
\text { smokers }\end{array}$ & $\begin{array}{c}\text { Cigarette only } \\
\text { smokers }\end{array}$ & $\begin{array}{c}\text { Both waterpipe } \\
\text { and cigarette } \\
\text { smokers }\end{array}$ \\
Factor & Mean (SD) & Mean (SD) & Mean (SD) & Mean (SD) \\
Negative health effects & $0.20(1.01)$ & $-0.09(0.97)$ & $-0.12(1.03)$ & $-0.16(0.94)$ \\
Positive personal benefits & $-0.12(1.04)$ & $0.04(0.98)$ & $-0.05(0.98)$ & $0.40(0.87)$ \\
Social reasons for smoking waterpipe & $0.16(1.03)$ & $-0.09(0.97)$ & $0.04(0.95)$ & $-0.25(0.97)$ \\
Negative personal effects & $0.11(1.02)$ & $-0.05(0.99)$ & $0.004(0.93)$ & $-0.26(0.98)$ \\
\hline
\end{tabular}

$S D=$ standard deviation. 
once to quit waterpipe smoking. More research is needed to explore the obstacles to quitting and the reasons why waterpipe smokers returned to smoking after trying to quit.

Some harmful behaviours, including cigarette smoking, are difficult to modify. As a consequence some public health officials have begun to consider harm reduction strategies, which aim to substitute a less harmful behaviour when eliminating the behaviour altogether is difficult to achieve [20].
Our results show that most waterpipe smokers smoked only 1 bowl per day, and smoked mostly at coffee houses. This raises the question whether public health policy should focus efforts on reducing cigarette smoking and be more permissive towards waterpipe smoking which is only an occasional social activity that occurs less than once a day.

Our data provide another glimpse of the patterns of waterpipe smoking in Kuwait. Some limitations in the collected data methods should be noted.
These data were gathered by trained data collectors in a variety of settings but do not represent a true random sample. The data were self-reported and there was no estimate of the truthfulness of the respondents, but there is also no evidence that respondents did not report valid answers. Accepting these shortcomings our data still provide useful information for quantifying certain aspects of waterpipe use and add to the limited information on waterpipe smoking that is presently available.

\section{References}

1. Knishkowy B, Amitai Y. Water-pipe smoking: an emerging health risk behavior. Pediatrics, 2005, 116(1):e113-e119.

2. Memon A et al. Epidemiology of smoking among Kuwaiti adults: prevalence, characteristics, and attitudes. Bulletin of the World Health Organization, 2000, 78(11):1306-1315.

3. Kandela P. Nargile smoking keeps Arabs in wonderland. Lancet, 2000, 356:1175.

4. Rees P. Briefing paper 3: sheesha smoking. March 2007:1-6 NHS Leicester City's Directorate of Public Health and Health Improvement [online document] (http://www.phleicester. org.uk/Documents/trs/Sheesha\%20Briefing\%20Paper.pdf, accessed 16 August 2010).

5. Shafagoj YA, Mohammed FI, Hadidi KA. Hubble-bubble (water pipe) smoking: levels of nicotine and cotinine in plasma, saliva, and urine. International Journal of Clinical Pharmacology and Therapeutics, 2002, 40(6):249-255.

6. Nafae A et al. Bronchogenic carcinoma in Kashmir valley. Indian Journal of Chest Disorders, 1973, 15:285-295.

7. Qiao Y-L et al. Relation of radon exposure and tobacco use to lung cancer among tin miners in Yunnan Province, China. American Journal of Industrial Medicine, 1989; 16:511-521.

8. Gunaid AA et al. Oesophageal and gastric carcinoma in the Republic of Yemen. British Journal of Cancer, 1995, 71:409-410.

9. Kiter $\mathrm{G}$ et al. Water-pipe smoking and pulmonary functions. Respiratory Medicine, 2000, 94:891-894.

10. Bayindir $U$ et al. The effect of water-pipe smoking on the peak flow rate [abstract]. European Respiratory Journal, 1993, 6(Suppl. 17):608.

11. Al Mutairi SS et al. Comparative analysis of the effects of hubble-bubble (sheesha) and cigarette smoking on respiratory and metabolic parameters in hubble-bubble and cigarette smokers. Respirology, 2006, 11(4): 449-455.

12. Al-Fayez SF, Ardawi SS, Zahran FM. Effect of sheesha and cigarette smoking on pulmonary function of Saudi males and females. Tropical and Geographical Medicine, 1988, 40:115-123.

13. Zahran FM, Ardawi SM, Attallah AA. Hazard of smoking sheesha in Saudi Arabia. Riyadh, Saudi Arabia, Directorate of Scientific Research, King Abdul College of Science and Technology, 1988.

14. Mohammed HRA, Newman IM, Tayeh, R. Sheesha smoking among a sample of future teachers in Kuwait. Kuwait Medical Journal, 2006, 38(2):107-113.

15. Mohammed HRA. Behaviors, attitudes, and knowledge toward smoking sheesha among selected students in a teacher certificate program in Kuwait [Dissertation]. Lincoln, Nebraska: University of Nebraska, 2003.

16. Green LW, Kreuter MW. Health program planning: an educational and ecological approach, 4th ed. New York City, McGraw-Hill, 2004.

17. Maziak W et al. Gender and smoking status-based analysis of views regarding water-pipe and cigarette smoking in Aleppo, Syria. Preventive Medicine, 2004, 38(4):479-484.

18. Allen J, Porter M, McFarland C. Leaders and followers in adolescent close friendships: susceptibility to peer influence as a predictor of risky behavior, friendship instability, and depression. Development and Psychopathology, 2006, 18(1):155-172.

19. Buehler C. Parents and peers in relation to early adolescent problem behavior. Journal of Marriage and Family, 2006, 68(1):109-124.

20. Stratton A et al. Clearing the smoke: the science base for tobacco harm reduction-executive summary. Tobacco Control, 2001, 10(2):189-195. 